\title{
Factors Related To The Incidence Of Breast Cancer In Women At Regional General Hospital Ulin Banjarmasin
}

\author{
Ahmad Hidayat ${ }^{1 *}$, \\ ${ }^{1}$ Sari Mulia Institute of Health Sciences Banjarmasin, Indonesia \\ *ahmadhidayat@stikessarimulia.ac.id \\ LaurensiaYunita $^{2}$ \\ ${ }^{2}$ Sari Mulia Academy of Midwifery Banjarmasin,Indonesia \\ Laurensia_yunita@akbidsarimulia.ac.id \\ Rita Enjel ${ }^{1}$ \\ ${ }^{1}$ Sari Mulia Institute of Health Sciences Banjarmasin, Indonesia \\ Rita_enjel@gmail.com
}

\begin{abstract}
Objective: knowing the factors related Incident of breast cancer at the Ulin General Hospital Area Banjarmasin.

Method: This research uses analytic Survey with the approach of the cross sectional. Population all women suffering discriminationTa cancer totaled 319 people, this research uses Simple Random Sampling with a sample of 178 samples with assay Chi-Square.

Results: The results showed that There is a relationship between age $(p=0.000)$, parity $(p=0.000)$ and a history of the use of hormonal $(\mathrm{KB} p=0.000)$ with the incidence of breast cancer in women where $\mathrm{p} \alpha$ value $<(0.05)$ as for the (family history $p=0.358)$ tidak there relationship with the occurrence of breast cancer in women where $\mathrm{p}>$ value $\alpha(0.05)$.

Conclusion: There are the relationship between age, parity, the use of hormonal contraception with a serious breast cancer and no relationship with a family history of breast cancer in women Regional General Hospital Ulin Banjarmasin.
\end{abstract}

Keywords : Cancer, Breast, Breast Cancer, Women

\section{INTRODUCTION}

Breast cancer is the most common cancer found in women. Estimated number of new cases is no less of $1,050,346$ per year. Of that number 580,000 cases occur in developed countries, the rest are in developing countries. Based on the estimated International Agency for Research on Cancer, in the year 2020 there will be 1.15 million new cases of breast cancer with 411,000 deaths. As much as $70 \%$ of new cases and $55 \%$ of deaths predicted would happen in developing countries [1].

The World Health Organization (WHO) 8$9 \%$ of women will experience breast cancer. Each year occur more than 250,000 new cases of breast cancer in the world and every year 44,000 patients died from this disease. The highest incidence is found in some regions of United States reach 
above 100 sufferers of 100,000 people. Then followed with some Western European countries, Switzerland's highest 73.5/100,000. For Asia still ranges between $10-20 / 100,000$ in specific areas such as Japan 17.6/100,000, Kuwait 17.2/100,000 and China 9.5/100,000 [2].

The study States that the risk of getting breast cancer increase in women who use HRT and increasing in line with the duration of use. The effect can be reduced

In Indonesia in the year 2012 the second positions for breast cancer causes cancer deaths that is $12.9 \%$ and new cases as much as $43.1 \%$, particularly in women, breast cancer occupying the position of the number one cause of death. In the year 2013 from the results of the checks conducted on breast cancer 645,436 people, it brings new cases as much as $61,682(9.56 \%)$. The highest case found in Central Java as much as $11.39 \%$ of new cases of breast cancer and in South Kalimantan on its own eventful obtained as much as $3.61 \%$ [3].

Breast cancer is the growth of breast cells that are not controlled due to the abnormal changes of the gene responsible Regulation of cell growth [4]. Breast cancer became one of the main causes of death for women in the world and in Indonesia. This cancer can happen to anyone and at any time. Breast cancer incidence was 20 years before the epidemic and not rarely occurs before the age of 30 years. But after that the incidence of breast cancer increased gradually and most found at the age of $35-50$ years and even today has begun to found at the age of 18 years. Figures for the incidence of breast cancer increased with increasing age.

Based on the results of data obtained from studies done on the introduction date of 4-7 February 2016, data obtained from the census book spaces chemotherapy HOSPITALS Ulin Banjarmasin in 2014 women who had breast cancer as much as 161 people $(43.51 \%)$ While in 2015 have elevated into 248 people $(77.7 \%)$ suffering from breast cancer.

\section{RESEARCH METHODS}

This research using the method Analityc Survey ith approach Cross Sectional. The population of the is a woman who is suffering from cancer chemotherapy at the Provincial Hospital Ulin Banjarmasin on January-December 2015 with the number of as much as the 319 .

sampling techniques Simple Random Sampling, i.e. simple random sampling of each Member of the population has an equal chance as the sample to get a sample as much of the 178 sample [5] 
Research on phases do researchers i.e. pertaMa medical record data by collecting women cancer patients in the medical record as many as 319 populations, after the data have been collected all next conducted random to get samples and documentation on using sheet checklist.

\section{RESULTS}

\section{Univariate Analysis}

Table 1 The Incidence Of Breast Cancer In Women

\begin{tabular}{|c|c|c|c|}
\hline No & Breast Cancer & $\mathrm{f}$ & $\%$ \\
\hline 1 & Positive Breast Cancer & 107 & $60,1 \%$ \\
\hline \multirow[t]{2}{*}{2} & Negative Breast Cancer & 71 & $39,9 \%$ \\
\hline & The total number of & 178 & $100 \%$ \\
\hline
\end{tabular}

respondents based on with breast cancer incidence in women. It brings about positive breast cancer as much as 107 people respondents $(60.1 \%)$ and negative breast cancer by as much as 71 (39.9\%) of the respondents people.

Table 2 Age In Women

\begin{tabular}{llcc}
\hline No & Age & f & $\%$ \\
\hline 1 & $23^{\text {th }}-39^{\text {th }}$ & 61 & $34,3 \%$ \\
\hline 2 & $40^{\text {th }}-74^{\text {th }}$ & 117 & $65,7 \%$ \\
\hline & The total number of & 178 & $100 \%$ \\
\hline
\end{tabular}

Based on table 2 Characteristics of respondents based on the respondents age in women. Obtained at age $23^{\text {th }}-39^{\text {th }}$ (not at risk) as many as 61 people $(34.3 \%)$ and at the age of $40^{\text {th }}$ $74^{\text {th }}$ (at risk) as many as 117 people $(65.7 \%)$.

Table 3 Parity In Women

\begin{tabular}{llcc}
\hline No & Parity & $\mathrm{f}$ & $\%$ \\
\hline 1 & 0 (at risk) & 34 & $19,1 \%$ \\
\hline 2 & $1-7$ (not at risk) & 144 & $80,9 \%$ \\
\hline & The total number of & 178 & $100 \%$ \\
\hline
\end{tabular}

Based on table 3 Characteristics of respondents based on parity. On the research results obtained are at risk as much as 34 people (19.1\%) and are not at risk as much as 144 people $(80.9 \%)$

Table 4 Family History Of Experiencing Cancer Payuda In Women

\begin{tabular}{llcc}
\hline No & Family History & f & $\%$ \\
\hline 1 & Ada & 63 & $35,4 \%$ \\
\hline 2 & Tidak Ada & 115 & $64,6 \%$ \\
\hline & The total number of & 178 & $100 \%$ \\
\hline
\end{tabular}

Based on table 4 Characteristics of respondents based on a family history of breast cancer in women. Obtained that have a family history of breast cancer by as much as 63 people (35.4\%) and who do not have a history of breast cancer in her family as much as 115 people $(64.6 \%)$.

Table 5 The use of Hormonal Contraceptives (Pill, Implant, Injection) in women

\begin{tabular}{llcc}
\hline No & $\begin{array}{l}\text { The Use Of Hormonal } \\
\text { Contraception }\end{array}$ & $\mathrm{f}$ & $\%$ \\
\hline 1 & Use & 147 & $82,5 \%$ \\
\hline 2 & Do Not Use The & 31 & $17,4 \%$ \\
\hline & The total number of & 178 & $100 \%$ \\
\hline
\end{tabular}

Based on table 5 Characteristics of respondents based on the use of hormonal contraceptives on the history of women. Obtained that have a history of using hormonal contraceptives as many as 147 people $(82.5 \%)$ and were not using hormonal contraceptives as many as 31 people $(17.4 \%)$. 


\section{Bivariate Analysis}

In this study analyzed the relationship of fakTor-factors associated with the incidence of breast cancer in women at the PROVINCIAL HOSPITAL Ulin Banjarmasin.

Table 6 Analysis Of The Relationship Of Age With Incidence Of Breast Cancer In Women

\begin{tabular}{|c|c|c|c|c|c|c|c|c|c|}
\hline \multirow[t]{3}{*}{$\begin{array}{l}\mathrm{N} \\
\mathrm{O}\end{array}$} & \multirow[t]{3}{*}{ Age } & \multicolumn{4}{|c|}{$\begin{array}{c}\text { The Incidence Of } \\
\text { Breast Cancer }\end{array}$} & \multicolumn{4}{|c|}{$\begin{array}{l}\text { The } \\
\text { total } \\
\text { number } \\
\text { of }\end{array}$} \\
\hline & & & ive & & tive & & $(\%$ & $\mathrm{P}$ & $\mathrm{Od}$ \\
\hline & & $f$ & $\%$ & $\mathrm{f}$ & $\%$ & $\mathrm{f}$ & ) & $\begin{array}{l}\text { Va } \\
\text { lue }\end{array}$ & $\begin{array}{l}\text { ds } \\
\text { Rat }\end{array}$ \\
\hline 1 & $\begin{array}{l}23^{\text {th }}- \\
39^{\text {th }}\end{array}$ & 20 & $\begin{array}{l}32 \\
8 \\
\%\end{array}$ & 41 & $\begin{array}{l}67 \\
2 \%\end{array}$ & $\begin{array}{l}6 \\
1\end{array}$ & $\begin{array}{c}10 \\
0 \%\end{array}$ & $\begin{array}{l}0,0 \\
00\end{array}$ & $\begin{array}{l}5.9 \\
45\end{array}$ \\
\hline 2 & $\begin{array}{l}40^{\text {th }}- \\
74^{\text {th }}\end{array}$ & 87 & $\begin{array}{l}74 \\
, 4 \\
\%\end{array}$ & 30 & $\begin{array}{l}25, \\
6 \%\end{array}$ & $\begin{array}{l}1 \\
1 \\
7\end{array}$ & $\begin{array}{l}10 \\
0 \%\end{array}$ & & \\
\hline & $\begin{array}{l}\text { total } \\
\text { beer of }\end{array}$ & $\begin{array}{c}10 \\
7\end{array}$ & $\begin{array}{l}60 \\
1 \\
\%\end{array}$ & 71 & $\begin{array}{l}39, \\
9 \%\end{array}$ & $\begin{array}{l}1 \\
7 \\
8\end{array}$ & $\begin{array}{l}10 \\
0 \%\end{array}$ & & \\
\hline
\end{tabular}

Based on table 6 The characteristics of the respondents on the basis of age in women. Obtained results by age 40 years $>$ positive breast cancer by as much as 87 people $(74.4 \%)$ and 40 years of age as a negative > breast cancer by as much as 30 people $(25.6 \%)$ while at the age of 40 years of positive < breast cancer by as much as 20 people $(32.8 \%)$ and at the age 40 years of negative $<$ breast cancer by as much as 41 men $(67.2 \%)$.

Based on test results Chi-Square obtained values $p=$ the values $0000 p 0.05$, so can < concluded that there is a relationship between the age of $40^{\text {th }}-74^{\text {th }}$ (At risk) and the incidence of breast cancer in women. Mothers with age 40 years have $>5,945$ times to risky the occurrence of breast cancer compared to women aged 40 years $<$.

Table 7 Analysis Of The Relationship Of Parity With The Incidence Of Breast Cancer In Women

\begin{tabular}{|c|c|c|c|c|c|c|c|c|c|}
\hline \multirow[t]{3}{*}{$\begin{array}{l}\mathrm{N} \\
\mathrm{O}\end{array}$} & \multirow[t]{3}{*}{ Parity } & \multicolumn{4}{|c|}{$\begin{array}{c}\text { The Incidence Of } \\
\text { Breast Cancer }\end{array}$} & \multicolumn{3}{|c|}{$\begin{array}{l}\text { The total } \\
\text { number of }\end{array}$} & \multirow{3}{*}{$\begin{array}{l}O d \\
d s \\
R a \\
\text { tio }\end{array}$} \\
\hline & & \multicolumn{2}{|c|}{$\begin{array}{c}\text { Positiv } \\
\mathrm{e}\end{array}$} & \multicolumn{2}{|c|}{$\begin{array}{c}\text { Negati } \\
\text { ve }\end{array}$} & \multirow[t]{2}{*}{$\mathrm{f}$} & \multirow[t]{2}{*}{$(\%)$} & \multirow{2}{*}{$\begin{array}{c}P \\
V a \\
l u \\
e\end{array}$} & \\
\hline & & $\mathrm{f}$ & $\%$ & $\mathrm{f}$ & $\%$ & & & & \\
\hline 1 & $\begin{array}{l}\text { At } \\
\text { risk }\end{array}$ & 6 & $\begin{array}{c}17 \\
6 \\
\%\end{array}$ & $\begin{array}{l}2 \\
8\end{array}$ & $\begin{array}{c}82, \\
4 \\
\%\end{array}$ & $\begin{array}{l}3 \\
4\end{array}$ & $\begin{array}{c}100 \\
\%\end{array}$ & $\begin{array}{l}0, \\
00\end{array}$ & $\begin{array}{l}0.0 \\
91\end{array}$ \\
\hline 2 & $\begin{array}{l}\text { Not at } \\
\text { risk }\end{array}$ & $\begin{array}{l}1 \\
0 \\
1\end{array}$ & $\begin{array}{c}70 \\
1 \\
\%\end{array}$ & $\begin{array}{l}4 \\
3\end{array}$ & $\begin{array}{c}29 \\
9 \\
\%\end{array}$ & $\begin{array}{l}1 \\
4 \\
4\end{array}$ & $\begin{array}{c}100 \\
\%\end{array}$ & 0 & \\
\hline $\begin{array}{l}\text { to } \\
\text { of }\end{array}$ & $\begin{array}{l}\text { The } \\
\text { number }\end{array}$ & $\begin{array}{l}1 \\
0 \\
7\end{array}$ & $\begin{array}{c}60, \\
1 \\
\%\end{array}$ & $\begin{array}{l}7 \\
1\end{array}$ & $\begin{array}{c}39 \\
9 \\
\%\end{array}$ & $\begin{array}{l}1 \\
7 \\
8\end{array}$ & $\begin{array}{c}100 \\
\%\end{array}$ & & \\
\hline
\end{tabular}

Based on table 7 Characteristics of respondents based on parity in women. Obtained results with a positive risk of breast cancer by as much as 6 people (17.6\%) and the negative risk of breast cancer by as much as 28 people $(82.4 \%)$ whereas in the not at risk-positive breast cancer as much as 101 people $(70.1 \%)$ and not a negative risk of breast cancer by as much as 43 people $(29.9 \%)$

Based on test results Chi-Square obtained values $p=$ the values $0000 p 0.05$, so can < concluded that there is a relationship between the parity with breast cancer incidence in women. Women with parity not at risk (primipara, multipara, grandemulti) have 0091 time to put at risk the occurrence of breast cancer compared to women who are at risk (nulipara). 
Table 8 Analysis Of The Relationship Of Family History With The Incidence Of Breast Cancer In Women

\begin{tabular}{|c|c|c|c|c|c|c|c|c|}
\hline \multirow[t]{3}{*}{$\begin{array}{l}\mathrm{N} \\
\mathrm{O}\end{array}$} & \multirow[t]{3}{*}{$\begin{array}{l}\text { Family } \\
\text { History }\end{array}$} & \multicolumn{4}{|c|}{$\begin{array}{l}\text { The Incidence Of } \\
\text { Breast Cancer }\end{array}$} & \multicolumn{3}{|c|}{$\begin{array}{l}\text { The } \\
\text { total } \\
\text { number } \\
\text { of }\end{array}$} \\
\hline & & \multicolumn{2}{|c|}{ Positive } & \multicolumn{2}{|c|}{$\begin{array}{c}\text { Negativ } \\
\mathrm{e}\end{array}$} & \multirow[t]{2}{*}{$\mathrm{f}$} & \multirow[t]{2}{*}{$\begin{array}{c}(\% \\
)\end{array}$} & \multirow{2}{*}{$\begin{array}{c}P \\
V a \\
\text { ue }\end{array}$} \\
\hline & & f & $\%$ & $\mathrm{f}$ & $\%$ & & & \\
\hline 1 & Ada & 35 & $\begin{array}{c}55,6 \\
\%\end{array}$ & $\begin{array}{l}2 \\
8\end{array}$ & $\begin{array}{l}44, \\
4 \%\end{array}$ & $\begin{array}{l}6 \\
3\end{array}$ & $\begin{array}{c}10 \\
0 \\
\%\end{array}$ & $\begin{array}{l}0,3 \\
58\end{array}$ \\
\hline 2 & $\begin{array}{l}\text { Tidak } \\
\text { Ada }\end{array}$ & 72 & $\begin{array}{c}62,6 \\
\%\end{array}$ & $\begin{array}{l}4 \\
3\end{array}$ & $\begin{array}{l}37, \\
4 \%\end{array}$ & $\begin{array}{l}1 \\
1 \\
5\end{array}$ & $\begin{array}{c}10 \\
0 \\
\%\end{array}$ & \\
\hline $\begin{array}{l}\text { total } \\
\text { of }\end{array}$ & $\begin{array}{l}\text { The } \\
\text { number }\end{array}$ & 107 & $\begin{array}{c}60,1 \\
\%\end{array}$ & 1 & $\begin{array}{l}39, \\
9 \%\end{array}$ & $\begin{array}{l}1 \\
7 \\
8\end{array}$ & $\begin{array}{c}10 \\
0 \\
\%\end{array}$ & \\
\hline
\end{tabular}

Based on table 8 Characteristics of respondents based on descent in women. The results obtained have family line positive breast cancer breast cancer by as much as 35 people (55.6\%) and who has a family lineage negative breast cancer breast cancer by as much as 28 people $(44.7 \%)$ whereas the results of which are not have descendants in the family a positive breast cancer breast cancer as much as 72 persons $(62.6 \%)$ and who have no family lineage negative breast cancer breast cancer by as much as 43 people $(37.4 \%)$.

Based on test results Chi-Square obtained values $p=0358$ the values $p>0.05$, so it can be concluded that there is no relationship between the descendants with breast cancer incidence in women.

Table 9 Analysis Of The Relationship Of Hormonal Contraceptive Use History With Breast Cancer Incidence In Women

\begin{tabular}{ccc} 
History & The Incidence & The \\
The Use Of & Of Breast & total \\
\hline
\end{tabular}

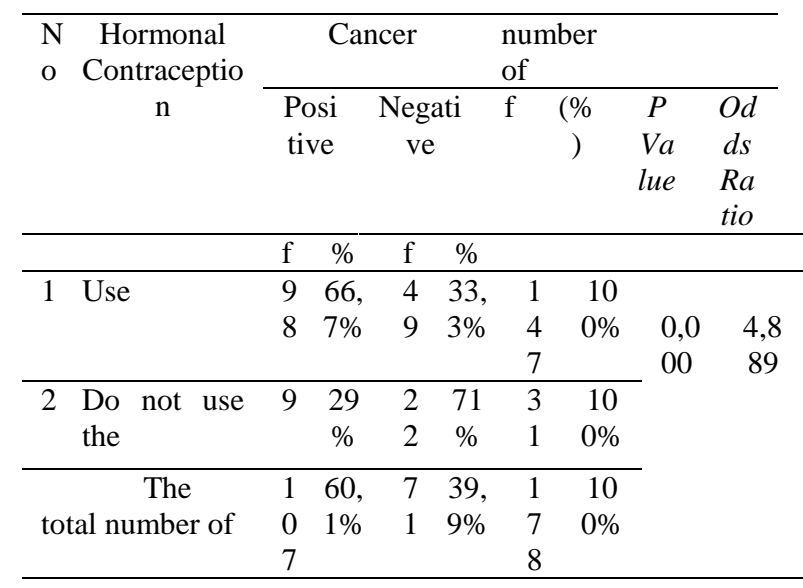

Based on table 9 Characteristics of respondents based on the use of hormonal contraceptives on the history of women. The results obtained using hormonal contraceptives positive breast cancer by as much as 98 people (66.7\%) and the use of hormonal contraceptives negative breast cancer by as much as 49 people (33.3\%) whereas the results of not using contraception positive hormonal breast cancer by as much as 9 people (29\%) and not using hormonal contraceptives negative breast cancer by as much as 22 people $(71 \%)$.

Based on test results Chi-Square obtained values $p=0000$ i.e. value $\mathrm{p} 0.05$, so can < concluded that there is a relationship between the use of hormonal contraceptives with breast cancer incidence in women and has 4,889 time to put at risk the occurrence of breast cancer than women who are not hormonal contraceptive. 


\section{DISCUSSION}

Based on table 6 relationship age with breast cancer incidence in women obtained research results that women that has aged 40 years > known from 117 respondents who experienced positive breast cancer that is as many as 87 people (74.4\%), negative breast cancer by as much as 30 people $(25.6 \%)$.

Of test results Chi-Square obtained $p=$ 0.000 meaning $p<0.05$ showed no relationship between age with incidence of breast cancer in women and retrieved the value Odds Ratio of 5,945 , meaning that women who age $>40$ tahthe UN has the breast cancer risk of 5,945 times compared to women aged 40 years $<$.

On the results of the study showed that the increase of the age then someone will be increasingly at risk for the occurrence of breast cancer are appropriate results obtained by researchers that most women who have aged 40 years would risk > experience of breast cancer compared to clients who have aged $\leq 39$ years old. This is because at the age of 40 years have > decreased body immunity system so that more potential to suffer from breast cancer.

On the research is in line with previous research based on previous studies said that there is a tendency of the risk of breast cancer with increasing age someone [6].
Opinions by researchers that age is fakTor is important for the occurrence of breast cancer in women because of someone's age increased progressively where it will be at risk of experiencing breast cancer is greater, because someone's staying power will be weakened in accordance with increasing age therefore the easier a person will experience a range of health problems including cancer of the breast.

The increase in the age of the person is always accompanied by a decrease in performance and immunity organs of his body. It makes it relatively easy to various infections and potentially cancer [10]

Based on table 7 relationship of parity with the incidence of breast cancer in women women with the results of the study respondents that is not at risk (Primipara, Multipara, Grandemulti) is known from 144 positive respondents experienced breast cancer that is as many as 101 people (70.1\%), negative breast cancer by as much as 43 people (29.9\%). Where the results of the test ChiSquare obtained $p=0.000$ meaning $p<0.05$ indicates the existence of a relationship between the parity with breast cancer incidence in women and retrieved the value Odds Ratio of 0.091. It means women with parity of primipara, multipara, grandemulti have 0091 time to put at risk the 
occurrence of breast cancer than women who never nulipara parity or childbirth.

The research is in line with previous research suggesting that parity multipara at risk have a meaningful chance of 4.571 at risk of suffering from breast cancer, compared with parity grandemutipara [7].

Parity is the number of children born by a woman or a mother of both living and dead. The effect of parity against the risk of breast cancer has long been scrutinized. In a study a metaanalysis reported that in women nulipara or have never given birth have a $30 \%$ risk to develop into breast cancer compared with women who multipara [1].

Opinions by researchers that parity is an important factor for the occurrence of breast cancer in women. Where the amount of the increase is getting a woman to give birth then someone is going to be more at risk of experiencing breast cancer is greater.

Based on table 8 relationship with a family history of breast cancer women with research results who have a family history of breast cancer are known from 63 the respondent's positive experience of breast cancer that is as many as 35 people (55.6\%), while respondents who do not have a history of breast cancer are known from
115 respondents are positive experience of breast cancer that is as much as 72 persons $(62.6 \%)$.

According the results of research undertaken by researchers. Here we can see that there is no link between a family history with the incidence of breast cancer in women. So that the clients who have a history of breast cancer are not at risk for the occurrence of breast cancer in which the results of test Chi-Square earned value $p$ $=0.358$ meaning $p>0.05$ indicates the absence of a relationship with a family history of breast cancer in women.

This contrasts with the opinion of the experts that form a strong family, a lot of women who have breast cancer with mutation called BRCA 1 in chromosome 17 which it is estimated that $86 \%$ of these women will get breast cancer at the age of 70 of the year. When a mother or sister who had breast cancer, the risk will be that for women affected by breast cancer will rise two or three fold. And have a mother and sister with breast cancer would increase the risk of developing cancer Breast into six times [8].

Hacyl study are inconsistent on the results of previous research that says that a family history as one of the factors for the incidence of breast cancer in women [6].

Based on table 9 hormonal contraceptive use relationship with incidence of breast cancer in 
women with the results the use of hormonal contraceptives are known from 147 respondents who experienced positive breast cancer that is as much as 98 people $(66.7 \%)$, while respondents who do not use hormonal contraceptives are known from the 31 respondents were positive experience of breast cancer that is as much as 8 people (29\%).

According the results of research undertaken by researchers. Here we can see that there is a relationship between the use of hormonal contraceptives with breast cancer incidence in women. Where the results of the test Chi-Square obtained $p=0.000$ meaning $p<0.05$ indicates the presence of hormonal contraceptive use relationship with breast cancer incidence in women and retrieved the value Odds Ratio of 4,889 , meaning that women who use hormonal contraceptives have a risk of 4,889 times suffer from breast cancer compared to women who did not use hormonal contraceptives.

On the research is in line with previous research based on previous studies said that there is a tendency of the risk of breast cancer with the use of hormonal contraceptives with. Where obtained on previous research value of hormonal contraceptive use OR have opportunities 3.431 are at risk of suffering from breast cancer than do not use hormonal contraceptives [7].
There was an earlier research claimed that contraception is a tool to control the pregnancy. Different types of birth control have advantages or disadvantages or side effects that must be known. Contraceptives are more problematic and hormonal contraceptive used in the long term increase the risk of cervical cancer by as much as 1.5-2.5 times [10].

The content of estrogen and progesterone on hormonal contraceptives would give excess proliferation effect on breast ephitelium duct, berlebinya the process of proliferation when followed by loss of control over the proliferation of cell death and arrangements a cell that is already programmed will result in breast cells conduct proliferate continuously without any limits. The loss of the more exotici cell death is a hard-wired inability to detect this will cause cell damage due to damage to the DNA so the abnormal cells will conduct proliferate the directly controlled without menurus [9].

The opinion of the researchers, that high hormone levels during the period of reproductive females especially if not punctuated by hormonal changes due to pregnancy, seems to increase the chances of growth of cells that have been genetically damaged and cause cancer. Women who use this drug for a long time will have a high risk for experiencing breast cancer before 
menopause. Cells that are sensitive to hormonal stimulation may experience changes into a benign or malignant degeneration.

\section{CONCLUSION}

Based on the results of research and discussion that have been previously described. stating that ada relationships between age $(p=$ 0.000 ) and the incidence of breast cancer in women category where women aged 40-74 years are at risk of the occurrence of breast cancer, there is a relationship of parity $(p=0.000)$ and the incidence of breast cancer in women can be seen from the results of research that the category of primipara and multipara, parity grande multi has a risk of occurrence of breast cancer, there is a hormonal contraceptive use history relationship ( $p=0.000)$ with the incidence of breast cancer It can be seen from the results of research that the category of women who use hormonal contraception hypodermic-like as many as 56 people (52.3\%), pills as much as 33 persons $(30.9 \%)$ are at risk of the occurrence of breast cancer, and tidak there relationship family history $(p=0.358)$ with the incidence of breast cancer in women.

Age and the use of hormonal contraception is as a factor the risk, while protective factors in parity for the occurrence of breast cancer in women.
Expected to do research on different variables using primary data in order to dig further factors associated with breast cancer.

\section{REFERENCES}

[1]. Rasjidi, Imam. 2010. Epidemiologi Kanker pada Wanita. Jakarta: Kompas Gramedia.

[2]. Purwoastuti, Endang. 2008. Kanker Payudara. Yogyakarta: Kanisius.

[3]. Riskesdas, R1. 2015. Badan Penelitian dan Pengembangan Kesehatan.

[4]. Suprianto, Wawan. 2010. Ancaman Penyakit Kanker Deteksi Dini dan Pengobatanya. Yogyakarta: Cahaya Ilmu.

[5]. Notoatmodjo, Soekidjo. 2010. Metode Penelitian Kesehatan. Jakarta.: PT. Rineka Cipta.

[6]. Haslinda. (2013). Faktor Resiko Kejadian Kanker Payudara di RSUP DR. Wahidin Sudirohusodo Makasar. ISSN: 2302-1721. Skripsi V2No.1

[7]. Abidin, dkk. 2013. Faktor Risiko Kejadian Kanker Payudara Di RSUD Lambuang Baji Makasar. ISSN: 2302-1721. Skripsi V4No.2

[8]. Irene. (2008). Kanker Payudara Penyembuhan Dengan Herbal. (Online) http:

//www.cancerhelps.com/kankerpayudara.ht m, diakses 9 juni 2016.

[9]. Indriati, Rini. (2005). Faktor Resiko yang Berpengaruh Terhadap Kejadian Kanker Payudara Wanita di Rumah Sakit Dokter Kariadi Semarang. Program Pascasarjana Universitas di Ponegoro: Semarang

[10]. Ramli, Muchlis, Management Of Brest Cancer; dalam kumpulan Naskah Ilmiah Muktamar VI PERABOI, Semarang 2003.

[11]. Syahda, Syukrianti. Faktor-faktor yang berhubungan dengan kejadian kanker serviks di RSUD Arifin Achmad Pekan Baru Tahun 2014. Jurnal Doppler, [S.I], V.G.n.2.P.17-26 Oct. 2017 ISSN 25803123.

[12]. Meister Kathleen, Morgan John, Risk Factor For Breast Cancer, American Council On Science And Health, 2000 